\title{
Integrating Multicultural Literature in EFL Teacher Training Curriculum
}

\author{
Ruwaida Abu Rass \\ Department of English, Beit Berl Academic College, Kfar Saba, Israel \\ Email: aburass@beitberl.ac.il
}

How to cite this paper: Rass, R. A. (2020). Integrating Multicultural Literature in EFL Teacher Training Curriculum. Open Journal of Modern Linguistics, 10, 588-598. https://doi.org/10.4236/ojml.2020.105035

Received: July 7, 2020

Accepted: October 23, 2020

Published: October 26, 2020

Copyright $\odot 2020$ by author(s) and Scientific Research Publishing Inc. This work is licensed under the Creative Commons Attribution International License (CC BY 4.0).

http://creativecommons.org/licenses/by/4.0/

\begin{abstract}
The paper addresses the need and importance of including literature of indigenous people and immigrants and their descendants in teaching English as a Foreign Language (EFL) worldwide, mainly in teacher training colleges. The aim is to qualify competent English teachers linguistically, cross-culturally, and morally who will be aware of social injustices, which would extend their roles as language teachers to become agents for change.
\end{abstract}

\section{Keywords}

Literature, EFL, Indigenous People, Immigrants, Multicultural Literature, Cross-Cultural Competence

\section{(c) (i) Open Access}

\section{Introduction}

In general, English speaking countries are constituted of different cultural groups that usually do not share the same values, traditions and styles of living. They also lack common social qualities in terms of race, language, gender, social class, physical and mental disorders. This situation is a result of immigration. Immigrants arrived at their shores at different times and due to different reasons and became an integral part of the society. However, they experienced stereotypes and prejudices, which nurture racism, discrimination and gross misinformation against other ethnic groups, promoting invisibility and concealing the social realities of sociocultural groups (Li, 2003, 2004).

To encounter racism and prejudice, many language educators believe in integrating the first culture of minority groups by including the literature of indigenous and immigrants and their offspring in the language curriculum. Tomalin (2008) describes culture as the fifth language skill (Tomalin, 2008), which involves different abilities, such as the ability to understand, accept, appreciate, 
and value cultural differences. According to Smith \& Riley (2009), culture "is understood as a patterned sphere of beliefs, values, symbols, signs, and discourses" (p. 2). All of these patterns are essential for literacy development. Language teachers are expected to include individual as well as community contexts in order to be well-connected culturally (Leavitt, 2011). By using culture, these pupils would have the opportunity to learn about themselves, to connect to school, and to succeed academically (Gay, 2000). However, since language and culture are inseparable (Bin Mohamed Ali \& Mohideen, 2016; Cakir, 2006; Honigefled, Giouroukakis, \& Garfinkel, 2011; Sailaja, 2013), language cannot be understood without reference to the target culture. Traditionally, the focus of EFL teaching has been on teaching the target culture, without acknowledging the learners' native culture (Bin Mohamed Ali \& Mohideen, 2016; Chlopek, 2008; Shin, Eslami, \& Chen, 2011). In this case, the target culture refers solely to the mainstream culture, which is Anglo-Saxon, not the culture of other ethnic groups that have become part of North American culture, mainly the United States and Canada.

As a result, Bin Mohamed Ali \& Mohideen (2016) propose ling cultural teaching, which means integrating language with the culture of other cultural and ethnic groups in teaching ESL/EFL since "English-speaking countries are not monocultural anymore, but increasingly multicultural" (p. 52). Therefore, incorporating learners' racial and cultural backgrounds is important for hearing their voices and empowering them (Shin, Eslami, \& Chen, 2011) to promote tolerance, understanding, acceptance and respect (Chlopek, 2008). The aim of multicultural education through literature is to develop not only the linguistic competence of learners, but also to raise their cultural awareness and cultural sensitivity.

Following this notion means including indigenous cultures and narratives of immigrants in the ESL curriculum in the English-speaking countries, which is essential for empowering the learners on the one hand. On the other hand, it is a way to decrease hetaerism and racism, aiming to promote cross-cultural understanding, acceptance of diversity and civic responsibility (Honigefled, Giouroukakis, \& Garfinkel, 2011). It would promote not only the linguistic competence of the students but also their cross-cultural or intercultural competence. It is also important to promote critical thinking (Cakir, 2006; Sercu, Mendez Garcia, \& Preito, 2004) by helping learners to think of other people who have contributed to humanity, despite differences and in becoming global citizens, tolerant of people of other faiths, ethnicities and nationalities. In addition, "diverse perspectives enlighten all students and allow them to explore and critically examine topics from multiple viewpoints" (Honigefled, Giouroukakis, \& Garfinkel, 2011: p. 29). By incorporating narratives of native and immigrant writers, learners will have the opportunity to broaden their horizons and to arouse their curiosity to know more about other countries and global issues in general (Bin Mohamed Ali \& Mohideen, 2016; Shin, Eslami, \& Chen, 2011). 
In this paper, I argue that there is room for such a perspective in EFL teacher training programs, as it is important to help future English teachers understand the reality of English-speaking countries and to see the acknowledgment of the "invisible" populations. It would also acquaint them with issues related to social and political tensions in countries of marginalized natives and immigrants such as the US and Canada, thus informing them about identity formation of these groups and their descendants.

Such a course is relevant to teacher-training programs worldwide since immigrants emigrated to English speaking countries from all over the world. Therefore, it would be an opportunity to expose EFL learners to the variety of reasons for immigration and to the unpleasant experiences of many immigrants who left their countries hoping to find a better life in a new country. Concepts such as colonialism, post colonialism, imperialism and communism could serve as topics of stories and discussion that would help learners construct knowledge about historical and sociocultural issues that have affected immigration to English speaking countries as well as the identities of the writers of these stories.

\section{Integrating Literature of Indigenous and Immigrant Writers in EFL Education}

In general, literature is a window into the lives of others and gives readers the opportunity to realize the existence of issues outside their lives (Landt, 2007; McGinnis, 2006). Learning about life through literature supports the personal growth and maturation process of readers (Aerila, Soininen, \& Merisuo-Storm, 2016). Besides serving as a stimulus for language development, literature arouses awareness of the target culture. In this context, literature as a window into both American history and way of life helps learners conceptualize knowledge about human reality. In addition, it should raise learners' cross-cultural awareness, promoting social cohesion.

Introducing multicultural literature in teaching English by including indigenous and immigrant literature immigration would challenge students' perceptions of cultures and deepen their understanding of diversity (Barfield \& Uzarski, 2009; Honigefled, Giouroukakis, \& Garfinkel, 2011). Multicultural literature refers to pieces of literature written by minority writers, which aim to enhance respect for diversity, Sims (as cited in Aerila, Soininen, \& Merisuo-Storm, 2016); therefore, in this context, literature of native people and immigrants is considered as multicultural literature. In addition, it is an opportunity for learners to appreciate the voices and identities of others (Honigefled, Giouroukakis, \& Garfinkel, 2011) and to develop their empathy to others. Kubota (2004) claims that language teachers usually are not prepared to understand social inequities and prejudices. Therefore, she proposes a critical multiculturalism curriculum to question the widespread norms and beliefs, aiming to raise student teachers' awareness of issues of injustice including race, class and cultural groups raised by authors who represent the voices of their own cultural groups. She asserts 
that if such issues are raised in EFL instruction, teachers will understand the injustices in society, which will ultimately enhance their own intercultural communicative competence. As a result, they will become agents for change who are motivated to promote intercultural competence in their pupils (Sercu, Mendez Garcia, \& Preito, 2004).

These discussions also reveal the relationship between the content of the stories and the motives of the writers. In addition, it is an opportunity to improve the English proficiency of the student teachers, helping them develop a habit of reading, exposing them to a wide variety of cultural contexts, while also keeping their language active and helping them produce language (Sailaja, 2013).

Including literature of indigenous people and immigrants in the curriculum could be an effective method to promote multiculturalism since it helps learners identify with their own culture since some selections are written by authors who belong to the learners' culture. They will also be exposed to other cultures, and open dialogues on issues regarding diversity. The classroom becomes a rich, multicultural environment that is accepting and inclusive. Such an environment might inspire EFL learners to be involved in social justice issues.

Since narratives are about good and bad experiences in the past and are related to the present, readers are emotionally and linguistically involved. The content of these stories is usually relevant to daily lives, so it might provoke feelings, thoughts and personal responses. In addition, literature, in general, is a world of fantasy, horror and visions put into words; therefore, it is a source of enjoyment that could be employed for instructional purposes. Moreover, integrating narratives of indigenous and immigrant groups in the EFL curriculum gives pre-service teachers the opportunity to meet many narratives and be exposed to different points of view, ideas, thoughts, and minds.

Literature, in general, has a personal value since it arouses empathy and helps learners "walk in someone else's shoes", explaining the life of others with different experiences and providing moral reasoning for concepts of right and wrong. Therefore, teaching literature of indigenous and immigrant writers promotes cross-cultural appreciation by acknowledging contributions of minorities (Arellano, 2011; Landt, 2006). In addition, readers are exposed to beliefs of others so that they can understand and accept others, their history, culture, and struggles. Exposing learners to the history and geography of the original countries of minority groups now English-speaking countries arouses respect, empathy and acceptance of all people, aiming to create a global community and raising social consciousness. As a result, students become aware of differences among people (Landit, 2006) and help eradicate prejudice while fostering empathy, tolerance and awareness of global problems. Furthermore, it illustrates similarities and common beliefs among the different religious groups in addition to acceptance of religious diversity as a reality, which enforces being proud of personal faith and assisting in finding one's identity in terms of their actions, beliefs and emotions (Peyton \& Jalongo, 2008). 
Studying the literature of indigenous people and immigrants is an opportunity to expose EFL student teachers to the multicultural reality and the lives of different ethnic groups in English speaking countries as modern pluralistic societies. Learners become aware of the variety of types and reasons for immigration. In terms of types, there are two types of immigration: forced immigration and voluntarily. The former refers to slavery and the latter includes several reasons such as escaping poverty, looking for better economic opportunities or escaping religious and political persecution (Kortenaar, 2009). For example, in the 20th century, immigrants were mainly European (Honigefled, Giouroukakis, \& Garfinkel, 2011) who fled first religious and political persecution or poverty after the Second World War (Kortenaar, 2009). In the 21st century, Asians and Latinos, who have immigrated voluntarily, seeking economic opportunities or being pushed by political expulsion, are considered as people of color and have experienced prejudice and discrimination in the United States (Sears, Fu, Henry, \& Bui, 2003).

In addition to expanding the horizons of EFL future teachers by acquainting them with types and reasons of immigration, they will learn about pleasant and unpleasant experiences, struggles and conflicts of many native people and immigrants who left their original countries hoping to find a better life in a new country. Discussing the content of the required short stories would increase the pre-service knowledge of cultural mismatches and conflicts as well as difficulties in adjustment of these writers and their communities in the melting pot of English-speaking countries at present. According to Aerila, Soininen \& Merisuo-Storm, 2016, multicultural literature enhances the learners' cultural awareness, helping them identify the "ethnicity-related experiences in an authentic voice" (p. 55).

Few researchers have investigated the concept of including literature of immigrants or multicultural literature in teacher training programs. The study of Gomez-Rodriguez (2015) investigated the use of the critical multicultural approach as an attempt to help EFL student teachers in Bogota, Colombia address the deep structure of the target culture, mainly in the USA, aiming to achieve intercultural communicative competence. The concept of deep structure refers to social class struggles, poverty, cultural loss and prejudices. The findings show that EFL pre-service teachers were able to build their critical thinking abilities and intercultural awareness when they read English stories that discussed the above examples of deep culture written by authors who represent the voices of their communities. The researcher concluded the relevance of including deep culture in terms of traditions, beliefs, assumptions and values in EFL teacher training programs to raise awareness of social injustices.

\section{Implications for Teaching}

The above discussion by different researchers and EFL educators should be considered for designing a course that deals specifically with literature and narra- 
tives by indigenous and immigrant writers in English-speaking countries. To do so successfully, texts must be understandable, meaningful and predictable. In addition, the content, characters and situations of the text must be within the realm of reality. For example, a well-portrayed character can become a friend, a model or a temporary parent. Literary texts should be carefully selected in terms of developmental appropriateness, quality of writing, relevance of issues to students, believability of characters, interest level of the story and realistic social issues (Landt, 2006). The theme is also important since it underlines the meaning or significance of the moral of the story. Selecting stories that help in promoting multiculturalism is an important issue that should be considered seriously. Landt (2006) recommended the following categories: presenting accurate portrayal of the culture, showing diversity within the culture, including accurate representation of the oral cultures, depicting realistic social issues and showing minority characters as leaders who solve problems in their communities. Salas, Lucido and Canales (2001) add some other criteria such as the authenticity of characters, not stereotyped, and the richness in terms of cultural details

Life stories of families of ethnic minority groups such as Chinese and Middle Eastern families in the North American school population of the USA and Canada could serve as good authentic materials for EFL teacher training programs. The American and Canadian education systems are different than Chinese and Middle Eastern systems and adopt different cultural and educational values. As a result, schoolchildren of these groups of immigrants face stereotypes (Derderian-Aghajanian \& Wang, 2012). In addition, Packard (2001) indicates that children from immigrant Chinese families experience an intergenerational, intercultural gap with parents in terms of language and traditions, and the cultural background is an essential aspect of personal identity. Mismatch between learners' primary discourse of home and the discourse at school affects identity formation (Derderian-Aghajanian \& Wang, 2012), which might be a useful topic for discussion in EFL college classrooms. Cultural differences in the family also affect immigrant students' adjustment and they might be cultural barriers in students' success at school (Derderian-Aghajanian \& Wang, 2012).

Since incorporating technology is one of the main principles for fostering education in the $21^{\text {st }}$ century, it could be utilized effectively for including pieces of children's literature aiming at promoting multiculturalism. Digital stories which are defined as short vignettes that combine the art of telling stories with multimedia objects including images, audio, and video (Rossiter \& Garcia, 2010), could be very helpful sources for not only for teaching English, but also for promoting tolerance and combating ignorance, prejudice, discrimination and hatred.

Additionally, instruction must be varied to include multiple sources of input such as the internet, movies, literature and music to help learners live the experience found in the content not just with their mental abilities, but also with all senses. Therefore, we recommend starting the course with a movie called "United States History Origins to 2000: Immigration and Cultural Change", which is 
part of the United States History Origins to 2000 DVD Series (2003). This movie portrays the reality in the United States as a country of immigrants, where some immigrants assimilated rapidly, while others endured difficulties in adapting to their new lifestyle. These immigrants did not have an easy cultural transition because they worked long hours in dangerous jobs, were underpaid and lived in poverty in urban slums. The aim of showing this movie is to give the students a chance to explore the history of North America, mainly the waves of different immigrant groups, their experiences and struggles in the new country.

I recommend introducing the story "Shooting an Elephant" by George Orwell, aiming to acquaint the students with the historical background of the hegemony of the British Empire in the $20^{\text {th }}$ century, the consequences of such hegemony on colonialized countries as well as the colonizing ones, and the importance of the English language in the world.

The focus will be on six stories that represent the lives of immigrants from different parts of the world, showing how to utilize the content of these stories to discuss cases of struggles of indigenous groups and cultural mismatches and conflicts between Chinese, Middle Eastern and Latino community members and the culture of the new country. To understand the historical development and events, especially in the USA, the first selection should represent the struggles of African Americans and discriminatory policies against them from slavery in the $18^{\text {th }}$ century to the $21^{\text {st }}$ century. More information about these recommended six stories appear (Table 1). In addition, the discussions will expose the learners to the difficulties in adjustment of these writers and their communities in the melting pot of English-speaking countries at present. See a list of other stories in Appendix.

Moreover, learners will be acquainted with the intergenerational conflicts between immigrants and their children who attended American schools. Such conflicts are obvious in the first two proposed stories: The Woman Warrior and The Joy Club. These narrations will also expose EFL learners to the struggles of working-class immigrants and their dreams of going back to their countries at the age of retirement, which were crushed by their harsh reality in North America.

\section{Pedagogical Recommendations}

As an introduction to the course, EFL instructors can show documentaries downloaded from the internet or ordered from production websites, to support their instruction with vivid pictures and sounds, showing the present lives of the mixed-colored citizens in North American as well as the tumultuous world changes of the $20^{\text {th }}$ century that caused massive immigration. In addition, showing such documentaries would empower student teachers worldwide. For example, the documentary called "A visit to a Mosque in America" includes visits of American people to a mosque in Cincinnati and interviews with Muslims of different colors and ethnicities, including Whites. This is a source not only for diffusing prejudices against American Muslims but also for empowering Muslim EFL viewers. 
Table 1. Recommended short stories.

\begin{tabular}{|c|c|c|c|}
\hline Title & Author & Themes & Summary \\
\hline Two Old Women & $\begin{array}{l}\text { Velma } \\
\text { Wallis }\end{array}$ & $\begin{array}{l}\text { Betrayal } \\
\text { Courage } \\
\text { Survival } \\
\text { Friendship }\end{array}$ & $\begin{array}{l}\text { This story is about two old women who were abandoned } \\
\text { by their tribe during a brutal winter famine. When they } \\
\text { were left alone, they worked hard to collect and dry fish } \\
\text { for themselves. The story shows the merciless way of } \\
\text { life of nomadic Native Canadians. }\end{array}$ \\
\hline $\begin{array}{l}\text { My Dungeon Shook: } \\
\text { A Letter to My Nephew }\end{array}$ & $\begin{array}{l}\text { James } \\
\text { Baldwin }\end{array}$ & $\begin{array}{l}\text { Racism } \\
\text { Sexism } \\
\text { Classism }\end{array}$ & $\begin{array}{l}\text { By writing a letter to his nephew, Baldwin aimed to make } \\
\text { white Americans aware of the painful realities of } \\
\text { African-American life, looking inward to examine the } \\
\text { psychological damage of racism and the search for black } \\
\text { identity and self-realization. }\end{array}$ \\
\hline $\begin{array}{l}\text { The Woman Warrior: } \\
\text { Memories of a } \\
\text { Girl among Ghosts }\end{array}$ & $\begin{array}{l}\text { Maxine } \\
\text { Hong } \\
\text { Kingston }\end{array}$ & $\begin{array}{l}\text { Intergenerational differences } \\
\text { Cultural mismatches } \\
\text { Women's position/Male dominance } \\
\text { Racism \& stereotyping } \\
\text { Living in between }\end{array}$ & $\begin{array}{l}\text { The story represents the experience of a young educated } \\
\text { woman who was born to a Chinese family. } \\
\text { On the one hand, the mother used to tell the story of a } \\
\text { swordswoman, a Chinese strong woman. On the other hand, } \\
\text { she expected her daughter to accept old Chinese traditions, } \\
\text { being submissive and silent. } \\
\text { In addition, the story is a mixture of fear, resentment, } \\
\text { displacement and disappointment. It shows how many } \\
\text { Chinese American families are torn between two worlds } \\
\text { without really being part of any of them. }\end{array}$ \\
\hline $\begin{array}{l}\text { The Joy Club: } \\
\text { Growing up } \\
\text { Asian American }\end{array}$ & Amy Tan & $\begin{array}{l}\text { Intergenerational differences } \\
\text { The challenges of cultural translation } \\
\text { The power of storytelling } \\
\text { The problem of immigrant identity } \\
\text { Sexism } \\
\text { Control over one's destiny }\end{array}$ & $\begin{array}{l}\text { The Joy Club includes six stories that represent the } \\
\text { intergenerational conflicts between Chinese mothers } \\
\text { and their American-raised daughters, experiencing } \\
\text { mismatches that stemmed from cultural differences. } \\
\text { The traditional Chinese values of obedience, } \\
\text { criticism and hiding emotions clash with the } \\
\text { daughter's American ideas about being independent. }\end{array}$ \\
\hline A Conversation & $\begin{array}{l}\text { Pauline } \\
\text { Kaldas }\end{array}$ & $\begin{array}{l}\text { Living in between } \\
\text { Dependent culture vs. } \\
\text { independent culture }\end{array}$ & $\begin{array}{l}\text { The story is about an Egyptian couple who left Egypt and } \\
\text { immigrated to the United States, revealing their intimate } \\
\text { struggles with identity and place. The wife appreciates the } \\
\text { possibilities of America, and the husband is tempted by the } \\
\text { desire to return home, embedded with loss of their homeland, } \\
\text { but he embraces both cultures. Their conversations portray } \\
\text { the differences in mentality, style of life and culture in both } \\
\text { countries, which shape the attitude of the wife. }\end{array}$ \\
\hline Nada & $\begin{array}{l}\text { Judith } \\
\text { Oritz Cofer }\end{array}$ & $\begin{array}{l}\text { Working class struggles } \\
\text { The American dream/illusion } \\
\text { Cultural, social and } \\
\text { religious conflicts }\end{array}$ & $\begin{array}{l}\text { This story represents the struggles of Latino working-class } \\
\text { people. The author talks about the story of Dona Ernestina, } \\
\text { a Latino woman who lived in the same apartment complex in } \\
\text { New Jersey with other people who immigrated to Mainland } \\
\text { America from Puerto Rico. This community tried hard to } \\
\text { maintain their Hispanic culture and ideals, keeping strong } \\
\text { social relations among themselves in the complex and } \\
\text { planning to go back to their original Island, Puerto Rico } \\
\text { when they would retire. } \\
\text { Dona lost her son to the Vietnam War shortly after the } \\
\text { death of her husband and refused the flag and medals } \\
\text { that the government people brought. After that visit, } \\
\text { she received a flag and medal, which she returned to the } \\
\text { government. The story ends with the mother giving away } \\
\text { all her worldly possessions, most of which were } \\
\text { made of plastic, and later committing suicide. }\end{array}$ \\
\hline
\end{tabular}


To facilitate reading, discussing and understanding the stories, course instructors use questions to organize learning. To guide learners to discover answers to questions, instructors can prepare a list of questions of lower- and higher-order thinking skills about the content of each reading selection and upload them to the course website. While questions of lower-order thinking skills ask about facts, higher-order thinking skills require them to analyze events and draw conclusions. These questions should be answered during class time, where students work in groups. Creating learning groups on-line would be helpful to give readers the chance to exchange ideas and discuss dilemmas and themes.

To involve EFL student teachers actively, inquiry based instruction, which emphasizes the learner's role and engagement in the learning process (Kidman, 2019), should be considered. Students could be given the chance to explore the lives of native and immigrant authors by preparing the biography of the writers in Power Point presentations and including short movies about them, their lives and experiences that influenced them to write their narratives. The student teachers should also show the world map locating the writers' original countries, to link between the historical events in these countries and the motives of the writers.

To vary the methods of involving learners in the course, some lessons could start with a free writing activity, where the course participants are invited to write about the main characters or events and share their writing in groups. Other times, in groups, they could respond to quotes from stories.

\section{Conclusion}

This paper explains the importance of including literature in indigenous and immigrant authors in English-speaking countries in the EFL teacher training curriculum, aiming not only to develop the literacy skills of the learners, but also to raise their awareness of racism, stereotypes against others who are different than them, and social injustices. The aim is to develop intercultural competence in appreciating their own cultures and others' cultures and contributions to the world, towards promoting multiculturalism. In return, EFL pre-service teachers would enhance their self-image as individuals in a particular minority group. In addition, their roles as EFL teachers would not be restricted to pedagogy and instruction. They will be agents for social change in this world.

\section{Conflicts of Interest}

The author declares no conflicts of interest regarding the publication of this paper.

\section{References}

Aerila, J. A., Soininen, M., \& Merisuo-Storm, T. (2016). Literature as a Tool in Multicultural Education: Perceptions of Finnish Student Teachers on Reading Multicultural Literature in Finland. Research and Reviews: Journal of Educational Studies, 2, 53-62. 
Arellano, J. (2011). The Use of Multicultural Literature in Elementary Classrooms: Teaching Acceptance and Understanding of Different Races, Ethnicities, and Cultures. A Research Paper Submitted in Partial Fulfillment of the Requirements for the Master of Science Degree, Menomonie, WI: Education, the Graduate School, the University of Wisconsin-Stout.

Barfield, S. C., \& Uzarski, J. (2009). Integrating Indigenous Cultures into English Language Teaching. English Teaching Forum, 1, 2-9.

Bin Mohamed Ali, H., \& Mohideen, Sh. (2016). Target Culture Teaching in the English as a Second/Foreign Language Classroom. Research Journal of English Language and Literature (RJELAL), 4, 47-52.

Cakir, I. (2006). Developing Cultural Awareness in Foreign Language Teaching. Turkish Online Journal of Distance Education, 7, 154-161.

Chlopek, Z. (2008). The Intercultural Approach to EFL Teaching and Learning. English Teaching Forum, 4, 10-19.

Derderian-Aghajanian, A., \& Wang, C. C. (2012). How Culture Affects on English Language Learners' (ELL's) Outcomes, with Chinese and Middle Eastern Immigrant Students. International Journal of Business and Social Science, 3, 172-180.

Gay, G. (2000). Culturally Responsive Teaching: Theory, Research and Practice. New York: Teachers College Press.

Gomez-Rodriguez, L. F. (2015). Critical Intercultural Learning through Topics of Deep Culture in an EFL Classroom. Medellin, Colombia, 20, 43-59.

Honigefled, A., Giouroukakis, V., \& Garfinkel, J. L. (2011). Immigrant Literature in the Secondary English Classroom: Rationale and Recommendations. The California Reader, 44, 25-31.

Kidman, G. (2019). Explainer: What Is Inquiry-Based Learning and How Does It Help Prepare Children for the Real World?

Kortenaar, N. T. (2009). Multiculturalism and Globalization. In C. A. Howells, \& E. M. Kroler (Eds.), The Cambridge History of Canadian Literature (pp. 556-571). Cambridge: Cambridge University Press. https://doi.org/10.1017/CHOL9780521868761.030

Kubota, R. (2004). Critical Multiculturalism and Second Language Education. In B. Norton, \& K. Toohey (Eds.), Critical Pedagogies and Language Learning (pp. 30-52). Cambridge: Cambridge University Press. https://doi.org/10.1017/CBO9781139524834.003

Landt, S. M. (2006). Multicultural Literature and Young Adolescents: A Kaleidoscope of Opportunity. Journal of Adolescent \& Adult Literacy, 49, 690-697. https://doi.org/10.1598/JAAL.49.8.5

Landt, S. M. (2007). Weaving Multicultural Literature into Middle School Curricula. Middle School Journal, 39, 19-24. https://doi.org/10.1080/00940771.2007.11461620

Leavitt, J. (2011). Linguistic Relativities: Language Diversity and Modern Thought. Cambridge: Cambridge University Press.

Li, G. (2003). Literacy, Culture, and Politics of Schooling: Counter Narratives of a Chinese Canadian Family. Anthropology and Education Quarterly, 34, 182-206. https://doi.org/10.1525/aeq.2003.34.2.182

Li, G. (2004). Perspectives on Struggling English Language Learners: Case Studies of Two Chinese-Canadians Children. Journal of Literacy Research, 36, 31-72. https://doi.org/10.1207/s15548430j1r3601_3

McGinnis, T. (2006). Considering the Possibilities: Using Multicultural Literature to Transform Practice. Voices from the Middle, 13, 23-26. 
Packard, B. L. (2001). When Your Mother Asks for Another Book: Fostering Intergenerational Exchange of Culturally Relevant Book. Journal of Adolescent and Adult Literacy, 44, 626-633.

Peyton, M. R., \& Jalongo, M. R. (2008). Make Me an Instrument of Your Peace: Honoring Religious Diversity and Modeling Respect for Faiths through Children's Literature. Early Childhood Education Journal, 35, 301-303. https://doi.org/10.1007/s10643-007-0231-2

Rossiter, M., \& Garcia, P. A. (2010). Digital Storytelling: A New Player on the Narrative Field. New Directions for Adult and Continuing Education, 126, 37-48. https://doi.org/10.1002/ace.370

Sailaja, P. (2013). The Context of English Teaching. The EFL Journal, 4, 43-49.

Salas, R. G., Lucido, F., \& Canales, J. (2001). Multicultural Literature: Broadening Young Children's Experiences. U.S. Department of Education Office of Educational Research and Improvement. Educational Resources Information Center (ERIC), ED 468866.

Sears, D. O., Fu, M., Henry, P. J., \& Bui, B. (2003). The Origins and Persistence of Ethnic Identity among the "New Immigrant" Groups. Social Psychology Quarterly, 66, 419-437. https://doi.org/10.2307/1519838

Sercu, L., Mendez Garcia, M. D., \& Prieto, P. C. (2004). Culture Teaching in Foreign Language Education. EFL Teachers in Spain as Cultural Mediators. Porta Linguarum, 1, 85-102.

Shin, J., Eslami, Z. R., \& Chen, W. Ch. (2011). Presentation of Local and International Culture in Current International English-Language Textbooks. Language, Culture and Curriculum, 24, 253-268. https://doi.org/10.1080/07908318.2011.614694

Smith, Ph., \& Riley, A. (2009). Cultural Theory (2nd ed.). Oxford: Blackwell.

Tomalin, B. (2008). Culture-The Fifth Language Skill.

http://www.teachingenglish.org.uk/articles/culture-fifth-language-skill

\section{Appendix}

\begin{tabular}{ccc}
\hline Title & Author & Affiliation \\
\hline Turtle Meat & Joseph Bruchac & Native American \\
A Short History of Indians in Canada & Thomas King & Native Canadian \\
My Soul Has Grown Deep & John Ddgar Wideman & African American \\
The Tenant & Bharati Mukherjee & Indian American \\
Never Marry a Mexican & Sandara Cisneros & Mexican American \\
The Tale of One Refugee & Eva Kende & Hungarian Canadian \\
The German Refujee & Bernand Malamud & Jewish American \\
Palestine 1966 & Suzan Moadi Darraj & Arab American \\
A Conversation with My Father & Grace Paley & Russian American \\
\hline
\end{tabular}

